ISSN 2078-6441. Вісник Львівського університету. Серія географічна. 2013. Випуск 44. С. 3-7. Visnyk of the Lviv University. Series Geography. 2013. Issue 44. P. 3-7.

631.4

теп н озняк

ьвівський н ціон льний університет імені в н

вул. . орошенк , 41, 79000, м. ввів, кр їн

ро н лізов но суч сний ст н грунтово-геогр фічних зн нь. озглянуто проблемні пит ння 3 конів геогр фічного поширення грунтів н земній поверхні, особливості прояву зон льності і поясності, ф ці льності, стрі льності, сенсорності т рефлекторності грунтів, екологічні принципи і підходи в геогр фії грунтів.

лючові слов : геогр фія грунтів, зон льність і поясність грунтів, рефлекторність і сенсорність грунтів, ф ці льність і стрі льність грунтів.

озвиток грунтово-геогр фічних зн нь з свідчує, що теоретичним фунд ментом геогр фії грунтів є вчення про грунт як продукт сукупної діяльності чинників грунтоутворення. огічний н слідок цього вчення - порівняльно-геогр фічний метод вивчення грунтів, який ст в основним методом геогр фії грунтів. уть його поляг $\epsilon$ в поєдн нні вивчення грунтів і чинників, які їх утворюють, у пильному зіст вленні всіх змін вл стивостей грунтів зі змін ми геогр фічних (екологічних) умов грунтоутворення.

орівняльно-геогр фічний метод потребує обов'язкового комплексного підходу до вивчення грунтів. цьому його основн цінність і н уково-методичне зн чення. ивч ючи 3 кономірності поширення грунтів у нерозривному зв'язку з чинник ми грунтоутворення, дослідники з'ясовують водноч с і генезу грунтів.

ироке з стосув ння порівняльно-геогр фічного методу д ло змогу уточнити прояви горизонт льної зон льності т вертик льної поясності в поширенні грунтів н поверхні емлі, зумовлені перев жно біоклім тичними чинник ми грунтоутворення.

ей метод допоміг з'ясув ти й інші з кономірності геогр фії грунтів і структури грунтового покриву, які визн чені впливом літогенних, геоморфологічних, історикогеологічних, п леогеогр фічних $\mathrm{T}$ інших особливостей природних умов різних континентів і регіонів.

т пними меж ми ст новлення суч сної геогр фії грунтів були докуч євське вчення про чинники грунтоутворення, його з кони, про широтні й вертик льні грунтові зони і пояси, погляди . p солов i . ер симов про функціон льнопровінці льну будову педосфери, вчення · рідл нд про структуру грунтового покриву. дослідженнях з геогр фії грунтів використовув ли всі розробки в г лузі грунтозн вств, які з'являлися н різних ст діях його розвитку, почин ючи від озн чення грунтового індивідуум т кл сифік ції грунтів і до н лізу їхньої еволюції, тлум чення полігенетичності т клім ксності грунтових різновидів, незворотності т циклічності грунтових процесів тощо.

історії геогр фії грунтів було переосмислення н укових зн нь про грунти, що виявилося в дискусіях про зон льні грунти і грунтову зон льність з г лом, про елемент рний грунтовий ре л і підходи до грунтово-геогр фічного р йонув ння, про роль

(C) озняк ., 2013 
різних чинників у формув нні грунтового покриву світу тощо. $\mathrm{K}$ н повненість зн ннями структурних ніш геогр фії грунтів свідчить про відносну ст дійну зрілість н уки. еогр фія грунтів м є об'ємну концепту льну б зу, розвинуту методологію, зн чний теоретичний і пр ктичний потенці л.

еогр фічність грунтів не є недок зовою. рунт, як і інші геогр фічні тіл , м є своє геогр фічне положення, тобто конкретне природне середовище, де він функціонує. явність у певному просторі комплексу природних умов визн ч є формув ння грунтів 3 певними вл стивостями. мін природних умов зумовлює з кономірні зміни вл стивостей грунтів. кий тісний зв'язок чинників грунтоутворення з основними генетичними вл стивостями грунтів ст новить суть визн чення грунту, порівняльногеогр фічний метод робить одним з головних у грунтово-геогр фічних дослідженнях. геогр фії грунтів основними дискусійними проблем ми є з кони геогр фічного поширення грунтів, які грунтуються н теорії про відсутність чи обмежене поширення н земній поверхні широтних зон і перев жне поширення зон льних типів грунтів.

н ліз грунтового покриву емлі з свідчив, що з кон зон льності виявляється в різних форм х, с ме: зрост нні різном нітності грунтів і їхньої контр стності від полярних широт до екв торі льних; ускл дненні скл ду і структури вертик льної поясності грунтового покриву гірських систем; збільшенні ємності т різном ніття типів хімізму біологічного колообігу елементів у системі грунт-рослин в гумідних і семигумідних л ндш фт х від високих широт до екв тор ; приуроченість до клім тичних поясів х р ктерних генетичних типів грунтів і кори звітрюв ння; смугов структуp грунтового покриву великих рівнин, ч сто широтного простяг ння з умов літологічно однорідної поверхні. кий х р ктер структури грунтового покриву розгляд ють як прояв 3 кону зон льності грунтів. ей з кон не суперечить іншим 3 кон м і принцип м геогр фії грунтів т не з перечує моз їчної, секторної, регіон льної й інших типів структури і моделей грунтового покриву. ротист влення їх, тим більше підмін зон льності принципом регіон льності не сприятиме розвитку теорії геогр фії грунтів.

искусійною проблемою геогр фії грунтів $є$ концепція клім тично зумовлених мег - і м кроструктур грунтового покриву - грунтово-геогр фічних поясів, зон, ф цій, провінцій тощо. дним з основних $з$ конів грунтоутворення $є 3$ кон зон льності. дн к конкретного формулюв ння цього з кону, т кож єдиного 3 г льноприйнятого поняття про явище, яке визн чене цим терміном, нем .

формульов ний . окуч євим емпіричний з кон грунтової і з г лом природної зон льності $є$ основним з коном геогр фії грунтів. скільки всі компоненти грунтоутворення розміщені н емлі у вигляді широтних смуг, то і грунти повинні розт шовув тися н земній поверхні зон льно. тож, ксіом твердить, що чинники грунтоутворення зон льні, оскільки грунт - функція чинників, то звідси робимо висновок, що грунт - зон льний.

ДН К 3 чинників грунтоутворення лише клім т $є$ зон льним, і перев жно тільки стосовно тепл . нші чинники, т кі як породи, рельєф, ч с, не м ють зон льного поширення. ому можн стверджув ти, що зон льність не може бути основним 3 коном геогр фії грунтів і грунт, як функція п'яти чинників, зон льним з яких є лише один, - не зон льний. роте зон льність є з г льноприйнятою в грунтозн встві, і основною т ксономічною одиницею грунтового р йонув ння $€$ грунтов зон .

процесі понятійно-термінологічних пошуків змінилося уявлення про с ме поняття “грунтов зон льність” як систему широтних смуг. е . окуч єв н голошув в, що 
н земній поверхні більше порушень 3 кономірностей зон льності, ніж проявів, тому й зон льність не є 3 г льним $з$ коном.

. ибірцев з зн ч в, що зон льність треб розгляд ти як “грубу схему”, оскільки земну поверхню “обтягують” не грунтові, теплові пояси, грунтові смуги н явні лише у тих вип дк х, коли клім тичні зони розділені н п р лельні одн до одної вторинні зони.

з с д х розуміння скл дності з г льних з конів геогр фії грунтів, підпорядков ності грунтів усім чинник м грунтоутворення можн стверджув ти, що типи грунтів у поширенні не обов'язково точно відповід ють меж м живих угрупов нь чи фізичних явищ, н прикл д зон м клім ту. ослідження . ер симов з свідчили, що суцільних клім тичних зон н емлі нем, вони поширені тільки окремими плям ми, тобто утворюють м кроклім ти, н підст ві яких виділяють грунтово-клім тичні ф ції. он льн ж 3 кономірність поширення грунтів є х р ктерною для внутрішньом терикових рівнин, зокрем , для хідноєвропейської рівнини.

жливу роль у геогр фічному поширенні грунтів відігр ють провінці льні (ф ці льні) зміни клім ту, спричинені головно місцевими термодин мічними тмосферними явищ ми, які ускл днюють широтну зон льність і сприяють появі специфічних місцевих явищ ж до формув ння особливих типів грунтів т індивіду льних 3 кономірностей їхнього геогр фічного розміщення.

сі грунти м ють зд тність сприйм ти вплив чинників грунтоутворення i відобр ж ти цей вплив у своїх вл стивостях, тобто м ють вл стивість рефлекторності.

слідком рефлекторності грунтів є їхня зд тність змінюв ти вл стивості в ч сі й просторі, виявляючи сенсорність. прямов ний х р ктер цих змін з послідовної зміни чинників грунтоутворення зумовлює секвентність. природі всі грунти рефлекторні т сенсорні до всіх комплексів чинників грунтоутворення.

йбільш поширеним явищем регіон льності грунтового покриву є стрі льність (смуг стість), тобто н явність н певній території декількох смуг 3 однорідним грунтовим покривом. лежно від того, який чинник спричиняє стрі льність, розрізняють клім тострі льність, фітострі льність, топострі льність тощо.

кремий н прям геогр фії грунтів - грунтово-геогр фічне р йонув ння. оно відобр ж є структуру грунтового покриву н різних рівнях орг ніз ції і слугує методом систем тиз ції зн нь з геогр фії грунтів. одноч с грунтово-геогр фічне р йонув ння $\epsilon$ н уковою основою пр ктичного використ ння к рт грунтів для оцінюв ння якості грунтового покриву i диференційов ного використ ння земельних фондів у різних г лузях господ рської діяльності. н ліз світових к рт грунтів з свідчив, що н них відобр жено н явну сьогодні суму зн нь зі світової геогр фії грунтів, водноч с вони є джерелом нових уз г льнень т утвердження основних принципів і з конів геогр фії грунтів.

ерспективним к ртогр фічним дослідженням є просторове різном ніття причин $\mathrm{i}$ видів руйнув ння т 3 бруднення грунтів, їхній зв'язок 3 природними т нтропогенними еколого-геогр фічними умов ми. ртогр фія грунтів повинн бути доповнен новим н прямом - розробленням і скл д нням к рт охорони і р ціон льного використ ння грунтів. p вильн орг ніз ція охорони і використ ння грунтів можлив лише н з с д х глибокого розуміння екологічного зн чення грунту в житті природи і людського суспільств . огляду н це в жливе теоретичне і методичне зн чення м є розвиток екологічних принципів і підходів у геогр фії грунтів. они повинні охоплюв ти вивчення як впливу чинників грунтоутворення н геогр фічне поширення грунтів, т к $\mathrm{i}$ 
зворотного впливу грунтів н різном ніття рослинного і тв ринного світу, н умови життя і господ рської діяльності людини. уч сн геогр фія грунтів щор з більше ст є н укою екологічною. е відобр ж ється в створенні спеці льних к рт грунтовоекологічного р йонув ння, т кож у розширенні легенд тр диційних грунтових к рт ун слідок включення в них критеріїв і пок зників, в жливих з екологічного погляду.

жливе зн чення для под льшого розвитку геогр фії грунтів м є вивчення еволюційно-генетичних зв'язків грунтового покриву з геологічною історією поверхні суші.

кі дослідження суттєво розширились з вдяки появі нових методів визн чення віку гірських порід і грунтів, успіх м п леогрунтозн вств і п леогеогр фії, четвертинної геології і п леобот ніки, геохімії і літології.

всіх ет п х розвитку грунтозн вств геогр фія грунтів бул в жливим н прямом у н уці про грунти. езпосередня уч сть грунтозн вців-геогр фів-к ртогр фів у вирішенні різном нітних пр ктичних пит нь освоєння, меліор ції, господ рського використ ння грунтів зб г тил грунтозн вство новими ф кт ми і м тері л ми для теоретичного пізн ння генези, геогр фії, екології, кл сифік ції грунтів, створюв л теоретичну основу для пізн ння з кономірностей еволюції грунтів і формув ння грунтового покриву.

оловним н уково-пр ктичним з вд нням геогр фії грунтів н нинішньому ет пі є розробк н укових основ і пр ктичних рекоменд цій з р ціон льного використ ння грунтів і охорони грунтового покриву відповідно до його зон льно-регіон льних і л ндш фтно-екологічних особливостей.

m ття:н дійшл до ред кщї 04.03.2013

доопр иьов н 04.04 .2013

прийнят до друку 17.06.2013

\section{ACTUAL PROBLEMS F GEOGRAPHY OF SOILS}

\section{Stepan Pozniak}

Ivan Franko National University of Lviv, P. Doroshenko St., 41, UA - 79000, Lviv, Ukraine

The present state of soil-geographical knowledge has been analyzed. The problems of geographical distribution of soils on the earth's surface, the peculiarities of it's zoning and zonation, soil distribution in accordance with landscape conditions, soil sensority and reflectivity, the ecological principles and approaches in geography of soils have been reviewed.

Key words: geography of soils, zoning, soil sensority and reflectivity, soil distribution in accordance with landscape conditions. 


\section{Степ н озняк}

ввовский н цион льный университет имени в н

$$
\text { ул. . орошенко, 41, 79000, г. ввов, кр ин }
$$

ро н лизиров но современное состояние почвенно-геогр фических зн ний. ссмотрено проблемные вопросы з конов геогр фического р спростр нения почв н земной поверхности, особенности проявления зон льности и поясности, ф ци льности, стри льности, сенсорности и рефлекторности почв, экологические принципы и подходы в геогр фии почв.

лючевые слов : геогр фия почв, зон льность и поясность почв, рефлекторность и сенсорность почв, ф ци льность и стри льность почв. 